\title{
Subtropical Atlantic Climate STUDIES (STACS): AN UPDATE
}

\author{
By Robert L. Molinari
}

$\mathrm{T}$ HE SUBTROPICAL Allantic Climate Sudies (STACS) of the National Oceanic and Atmospheric Administration (NOAA) is a multi-investigator. multi-institutional program (see Table 1 for participants) directed at (1) increased understanding of the role of western boundary currents of the Atlantic Ocean in meridional oceanic heat flux, and (2) development of strategies to monitor important western boundary features. The initial emphasis of STACS was on the subtropics (Molinari. 1983: Molinari. 1986) where earlier studies suggested that oceanic heat flux in the Atlantic is a maximum (e.g. Bryan ' $t$ al., 1975; Oort and Vonder Haar, 1976: Hastenrath, 1980). Other studies found that the Florida Current was a major component in the net oceanic heat flux at about the latitude of Miami (e.g.. Bryden and Hall, 1980). Thus, a two-year intensive observing period was conducted between 1982 and 1984 to study the role of the Florida Current in both the circulation of the subtropics and oceanic heat flux, as well as 10 devise sampling strategies for long-term monitoring of this western boundary current.

The results of this two-year study have provided additional insight into the structure and causes of the large variability observed in the thermal and velocity distributions of the Florida Current. At tidal frequencies, Mayer et al. (1984) and Mayer and Larsen (1986) provided new estimates for the volume transports of various tidal constituents. They also showed that tidal transport is largely one-dimensional (varying only in the along-channel direction) and simply related to coastal sea level. Lee $\operatorname{ct}$ al.(1985). Lee and Williams (1988), Johns and Schott (1988), and Schott 't al. (1988) describe the variability at time scales of day's to weeks and are able to relate the variability to local wind forcing. Leaman et al. (1987) considered the annual signal and its relation to basinwide wind forcing.

Additional effort has been directed at the annual and interamnual signals because of their possible relevance to climate problems. Modeling and statistical studies suggest that the annual signal can be

Robert L. Molinari. National Oceanic and Atmospheric Administration. Atlantic Oceanographic and Meteorological Adminustration.4301 Rickenbacker Causeway. Miamu. FL 33149. related to wind-stress curl distributions over the Atlantic interior, curl distributions over the Caribbean Sea. and local wind forcing over the Straits (as summarized in Rosenfeld et al.. 1989). Continued analysis of the data and model results are underway to resolve the relative importance of these different forcing mechanisms for Florida Current variahility. Although the amplitude of the interannual signal in Florida Current transport may be small (Schott and Zantopp. 1985). this signal could be particularly relevant in climate studies and is also being considered in more detail.

With respect to monitoring Flonida Curtent volume transport. Larsen and Sanford (1985) have shown that. when properly calibrated. potential difference measured across an inactive submarine communications cable at $27^{\circ} \mathrm{N}$ is capable of tracking Florida Current transport to better than $1.0 \times 10^{6} \mathrm{~m}^{3} \mathrm{~s}^{-1}$. Similarly, Maul ef al. (1985) have shown that coastal tide gauge stations are also capable of monitoring Florida Current transport variability. The accuracy is about a factor of two poorer than provided by cable. However. the tide gauge data do present the potential for obtaining a long historical record of Florida Current transport, a potential now being explored. Surface currents measured by high-frequency radar are another potential candidate for monitoring Florida current transport. Schott et al. (1986) found the surface flow to be well-correlated with transport variations over a time period of several weeks.

Beginning in mid-1984. STACS operational efforts became focused on circulation features along the Antillean Archipelago and the eastern Caribbean Sea. Sections were established at San Juan. Puerto Rico: Mayaguana, the Bahamas; and Abaco, the Bahamas (Fig. 1) to determine if western boundary currents in these areas play an important role in oceanic heat flux. In addition, sections were established in the Windward Passage and Caribbean Sea to address, in part. the question of the effects of regional forcing on Florida Current transport. Current profiling and CTD (Conductivity. Temperature and Depth) stations were occupied on all but the Mayaguana section, where only CTDs were taken. Section occupation through March 1989 is listed in Table 2. p. 35. In addition, current meter moorings 


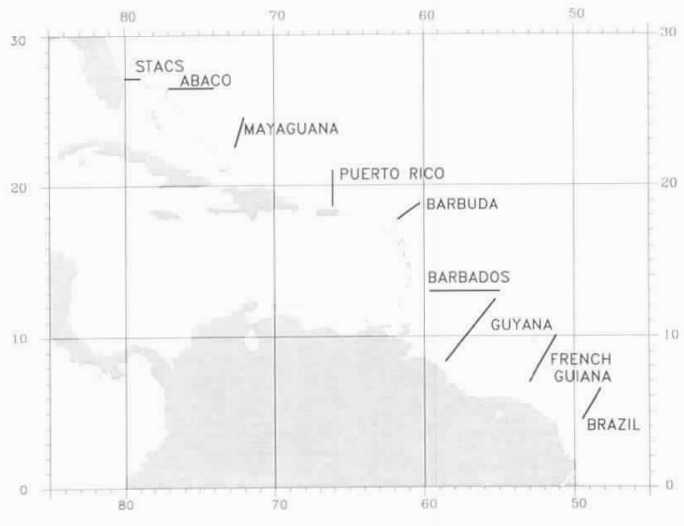

Fig. 1: STACS CTD and current profiler sections along the western boundary of the tropical and subtropical North Atlantic Ocean.

were deployed along the Abaco section by University of Miami scientists (see Table 1).

Several questions have been investigated using data from these sections. The volume transport data collected east of Abaco do not exhibit the large $\left(13 \times 10^{6} \mathrm{~m}^{3} \mathrm{~s}^{-1}\right)$, seasonally reversing boundary flow apparent in the model simulation of Anderson and Corry (1985). Rather the data are characterized by large transport events superimposed on a net southward flow (Rosenfeld et al., 1989). The continuous current meter data also do not indicate a dominant annual signal (Lee et al., 1988).

The large net transport to the south (ca. $35 \times 10^{6} \mathrm{~m}^{3} \mathrm{~s}^{-1}$, Leaman and Harris, 1990) through the Abaco section includes the Deep Western Boundary Current (DWBC). Using freon as a water mass tracer, Fine and Molinari (1988) show that the DWBC is continuous from Abaco to at least Barbados through the sections given in Fig. 1. However, the large mean transport of the flow below $1,000 \mathrm{~m}$ at Abaco is somewhat inconsistent with earlier estimates of the DWBC transport (Leaman and Harris, 1990).

The absence of a dominant annual signal in the direct current measurements at Abaco and the large southward transport below $1,000 \mathrm{~m}$ are two topics being considered in more detail. Specific questions include: Is the annual signal present but occurring over a large lateral distance with only a small, $\left[\sim 1 \mathrm{~cm} \mathrm{~s}^{-1}\right]$ velocity at any one station? What causes the large amplitude, $\left[\sim 30 \times 10^{6} \mathrm{~m}^{3} \mathrm{~s}^{-1}\right]$ higher-frequency variability observed at Abaco? Assuming that the southward Sverdrup interior transport is balanced by the northward transport of the Florida Current (Leetmaa et al., 1977), where does the $30 \mathrm{x}$ $10^{6} \mathrm{~m}^{3} \mathrm{~s}^{-1}$ southward transport off Abaco return northward?

Molinari et al. (1990) used the STACS Florida Current and Abaco observations and historical data compiled in the interior to generate an annual cycle of net oceanic heat flux through $26.5^{\circ} \mathrm{N}$. Their mean annual value of $1.2 \mathrm{pw}$ is very close to previous estimates of the flux at this latitude. The annual cycle does not have the southward transport computed for

TABLE 1: STACS PARTICIPANTS.

\begin{tabular}{|c|c|c|}
\hline PROGRAM & INVESTIGATOR & INSTITUTION \\
\hline $\begin{array}{l}\text { 1) Current meter moorings } \\
\text { off Abaco and French Guiana }\end{array}$ & $\begin{array}{l}\text { T. Lee } \\
\text { W. Johns }\end{array}$ & $\begin{array}{l}\text { Rosenstiel School of Marine and } \\
\text { Atmospheric Science (RSMAS), } \\
\text { University of Miami }\end{array}$ \\
\hline 2) Freon observations & R. Fine & RSMAS \\
\hline \multirow[t]{2}{*}{ 3) Pegasus observations } & K. Leaman & RSMAS \\
\hline & R. Molinari & $\begin{array}{l}\text { Atlantic Oceanographic and } \\
\text { Meteorological Laboratory } \\
(\text { AOML), NOAA }\end{array}$ \\
\hline 4) CTD observations & E. Johns & $\mathrm{AOML}$ \\
\hline $\begin{array}{l}\text { 5) Coastal tide gauge } \\
\text { observations }\end{array}$ & G. Maul & AOML \\
\hline $\begin{array}{l}\text { 6) Satellite altimetry, } \\
\text { IES, bottom pressure }\end{array}$ & G. Maul & AOML \\
\hline gauge observations & C. Rooth & $\begin{array}{l}\text { Cooperative Institute for Marine } \\
\text { and Atmospheric Science, } \\
\text { University of Miami }\end{array}$ \\
\hline 7) Cable observations & J. Larsen & $\begin{array}{l}\text { Pacific Marine Environmental } \\
\text { Laboratory, NOAA }\end{array}$ \\
\hline 8) Historical data review & D. Olson & RSMAS \\
\hline
\end{tabular}


the fall by Lamb and Bunker (1982) but has a very similar structure to the annual cycle simulated in a numerical model of the Atlantic Ocean by Sarmiento (1986).

The importance of the thermohaline circulation and DWBC in heat flux argues for monitoring of the section off Abaco. However, the large variability observed throughout the water column and over the entire section (Rosenfeld et al., 1989) indicates that some form of continuous observation is required for accurate monitoring. Thus, the current meter moorings presently in place will remain in the water at least through January 1990. Additional funds are being sought to continue these measurements. The use of satellite altimetry, inverted echo sounders and bottom pressure gauges for long term monitoring is also being studied.

One form of monitoring that has been implemented is the approximately once-per-year hydrographic cruise to the Abaco section to collect freon data. The importance of the DWBC to the thermohaline circulation and the changing water mass characteristics of this deep flow (indicative of changes in the intensity of air-sea interaction in the formation regions of these water masses (Fine and Molinari, 1988)) are the rationale for this monitoring. Regional freon surveys are also planned to study the ventilation of the interior waters by the boundary flow indicated in earlier observations (Fine and Molinari, 1988).

In contrast to the Pacific Ocean where the oceanic heat flux is symmetric (i.e., poleward) about the equator, the flux in the Atlantic is northward from pole to pole. Bjerknes (1964), for instance, has suggested that changes in the cross-equatorial heat flux have climatic implications. Using a numerical model simulation of the equatorial Atlantic circulation, Philander and Pacanowski (1986) show that the circulation in the western tropical Atlantic can play a significant role in the annual cycle of cross-equatorial heat flux. Thus, in September 1987 STACS began to occupy the southern sections shown in Fig. 1 to study cross-equatorial fluxes of heat, mass and momentum and tropical-subtropical interactions.

STACS cruises to the region were taken during September 1987; March, July and September 1988; and March 1989. In addition, to CTDs and a few Pegasus stations deployed along the French Guiana section, freon observations were taken during the February-March 1989 cruise. This cruise also included occupation of the western half of a transAtlantic section along $14.5^{\circ} \mathrm{N}$. The eastern half of the section was occupied by G. Siedler and T. Mueller of Kiel University, Federal Republic of Germany. Current meter moorings were deployed off French Guiana at the positions shown in Fig. 2 by T. Lee and W. Johns (Table 1).

Preliminary analysis of the CTD, Pegasus and first current meter mooring deployment data indicate a region rich in temporal and spatial variability. Johns and Molinari (1989) note that, as observed

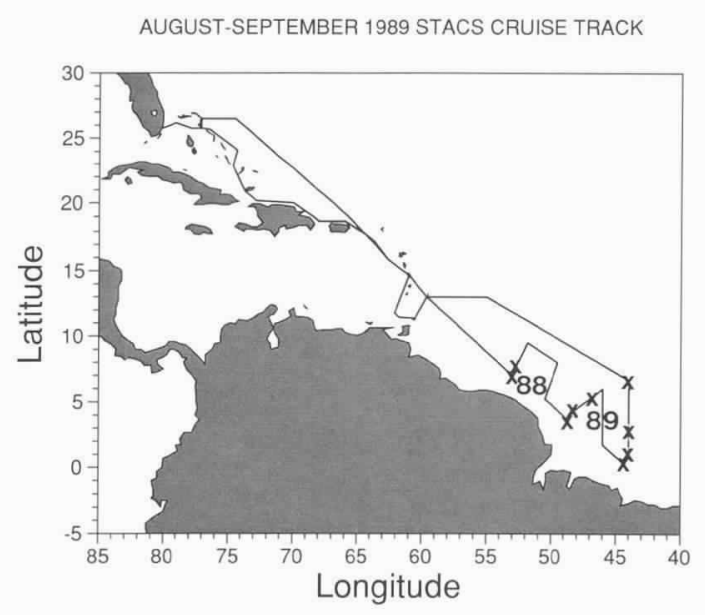

Fig. 2: STACS moorings deployed off French Guiana (88) and planned STACS/University of Kiel mooring positions to be deployed in fall 1989 and winter 1990 (89). Also shown is a tentative trackline for future STACS cruises to the region.

previously, surface layers are characterized by eddies of various horizontal and vertical extent. In addition, similar to model results, flow of southern hemisphere waters through the region is indicated in boreal winter but not summer. During boreal summer, the southern hemisphere waters turn offshore within the observational grid to feed the North Equatorial Countercurrent. Johns and Molinari (1989) using oxygen observations and Fine (1989, personal communication) extend the Fine and Molinari (1988) results of a continuous DWBC through the southern sections shown in Fig. 1. Current meter results in Johns et al. (1989) indicate that the DWBC is an intense boundary flow off French Guiana.

In fall 1989 and winter 1990, an array of seven moorings (three of which will be provided by $F$. Schott of the University of Kiel) will be deployed in a triangular array near the equator (Fig. 2). The array was designed to study cross equatorial fluxes and the feeding of several zonal equatorial flows by the boundary currents. Additional cruises are planned to the region at least through 1991. Tentative tracklines are shown in Fig. 2. A two-ship survey (R/V Baldrige and R/V Meteor) of the cross equatorial flow regime between $5^{\circ} \mathrm{N}$ and $5^{\circ} \mathrm{S}$ and west of $25^{\circ} \mathrm{N}$ is planned for fall 1990. The current meter deployments will continue through that time. Freon tracer data will be obtained on selected cruises to the region. Finally, model-observation comparisons are planned to provide a conceptual framework within which to analyze these measurements.

\section{References}

Anderson, D.L.T. and R.A. Corry, 1985: Seasonal transport variations in the Florida Straits: A model study. J. Phys. Oceanogr $., 15,773-786$. 
TABLE 2: SECTION OCCUPATIONS.

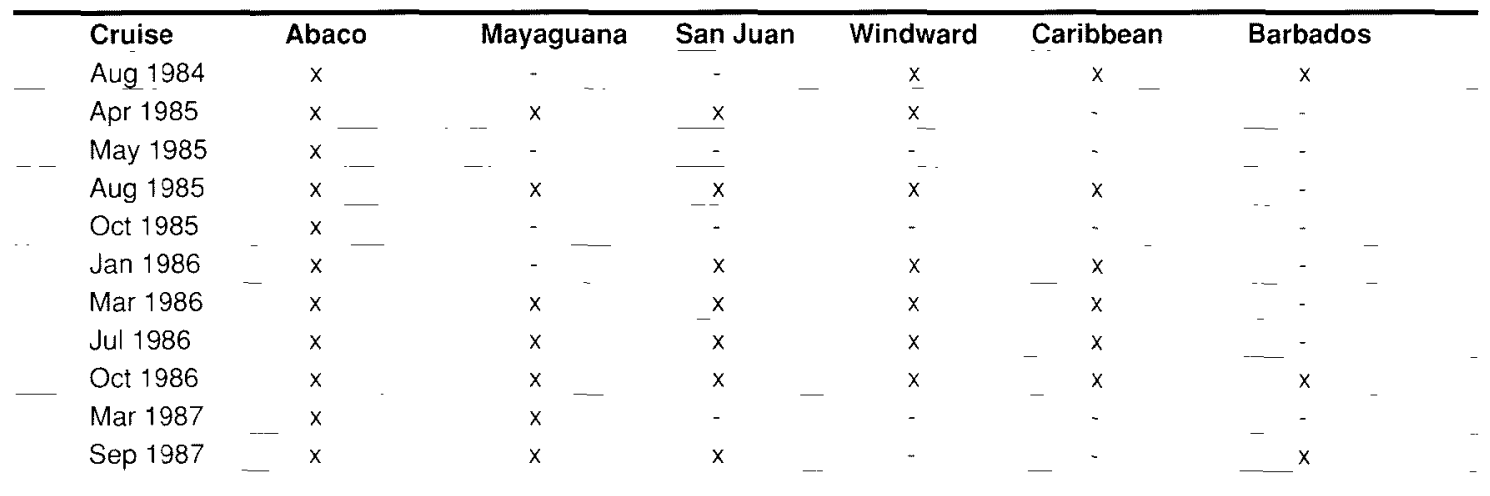

Bjerhnes. J.. 1964: Atlantic air-sea interaction. Ads. 1 Gorophlys. 11). $1-82$.

Bryan. K., S. Manabe, and R.C. Pancanowski. 1975: A global ocean-atmospere climate model. Part II. The oceanic circulaton. I. Phys. Oceunews..5. 30-46.

Bryden. H.L. and M.M. Hall. 1980: Ileat tramsport hy currents across 25" $\mathrm{Y}$ latitude m the Allantic Ocean. Sitenc', 207. 884.

Fine, R. and R.L. Molinari. 1988: A continuous deep western boundary currem between Abaco $(26.5 \mathrm{~N})$ and Barbados (13 N). Decep-Sea Re's. 35.14+1-1450.

Hastenrath. S.. 1980): Heat budget of troptcal ocean and atmosphere. I. Phis Oceunogr., 10. 159-170.

Johns. E. and R.L. Molinari. 1989: Recent current and water mass obervations along the sestem boundary of the tropical North Atlantic Ocian. LOS. 70, 360 .

Johns. W.E. and F. Schott. 1988: Meandering and transport variations of the Flondal Current. I. Phris. Ocecunest.. 17. $1128-1147$

Johns. W.E., T.N. Lee and R.J. Zintopp. 1989): Observations of boundary currents and 5()-day wases al 8 " $\mathrm{V}$ m the western tropical Alantic. EOS, 70,360 .

Lamb. P.J. and A.F. Bunker. 1982: The annual march of the heat budget of the north and tropical Atlantic Oceans. J. Phys. Occulerger, /2. $1.388-1409$.

Laren. J.C. and T.B. Sinford. 1985: Florida Current volume transports from vollage measurements. Sitence.227. 302$3(1)$.

Leaman. K.D.. R.L. Molinari and P.S. Vertes, 1987: Structure and variablity of the Florida Curren at $27^{\circ} \mathrm{N}$ : April 1982-July

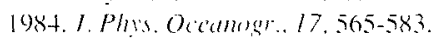

Leaman. K.D. and J.E. Harrs 1990): A note on the average abolute thansport of the Deep Wevern Boundary Current calst of Abaco Island, the Bahamas. I. Phys Oceancest... 20. (in press).

Lee. T.N. F. Schott and R. \%antopp. 1485: Flondal Current: Lowfrequency variabilly of the Florida Current as ohserved with moored current meter stations during April 1982 June 1983. Science. 227. 298-301.

Lee. T.N. and E. Williams. 1988: Wind-forced transport fluctuations of the Florida Current. I. Phys Ocenogr.. IS, 937-946.

Lee. T.N.. W. Jolms. R. Zantopp and E. Willizms. 1988: Structure and variability of western boundary currents east of the
Buhamas at 27 N. EOS, 69. 1236 .

Lectmita. A..P.P. Niiler and H. S1ommel. 1977: Does the Sverdrup relation aecount for the mid-Allantic circulation? J. Matr. Res...35.1-10.

Maul. G.A. F. Chew. M. Busmell and D.A. Maver, 1985: Sea level variation as an indicator of Florida Current volume transport. Comparisons with direct measurements. Sonence. $227,304-307$.

Mayer, D.A.. K.D. Leaman and T.N. Lee, 1984: Tidal motions in the Florida current. I. Phys. Ocecunegr. 14. 1551-1559.

Nayer. D.A. and J.C. L.arsen, 1986: Tudial transport in the Florita Current and its relation to tidal heights and cable voltages.

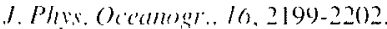

Molinari. R.L.. 1983: STACS: Subtropical Atlantic Climate Studies. Eos ot. 2 .

Molinari, R.L. 1086: Subtropical Adantic Climate Studies (STACS) revisited. EOS. 67. 59-60).

Molinari. R.L.. E. John and J.F. Festa. 1990): The annual cycle of meridional heat flux in the Atlantic Ocean at $26.5^{\circ} \mathrm{N} . I$ Phis. Oc callogr.. 20) (in press).

Oort. A.H. and T.H. Vonder I laar. 1976: On the obuerved annual cucle in the ocean-atmouphere beat balance over the

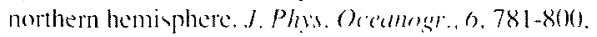

Philander, S.G.H., and R.C. Pacanowsh. 1986: The mass and heat hudget in a model of the tropical Atlantic Ocean. $I$ (icophly. Res., 91. 1+212-1+220).

Rosenfeld. L.K.. R.L. Molinari and K.D. Leaman, 1989: Observed and mosleled annual eycle of trannport in the Strats of Flonda and east of Abaco lsland. the Bahamas $\left(26.5^{\circ} \mathrm{N}\right)$. I. (ieophers Res.94. 4867-4878.

Sarmiento. J.. 1986: On the north and tropical Atlantic heat budget. I. Gorphys Re'., 9/.11677-11689.

Schott. F.A. and R. Zantopp. 1985: Florida Current: seasonal and interamnual variability. Setence', 227, 308-311.

Schott. F.A.. S.A. Frnch and J.C. Larsen. 1986: Compantson of surface current measured by HF Doppler Raldar in the western Florida Straits during November 1983 to January 1984 and Floridat Current transports. I. Geophys. Res., 91. $8+51-8+60$

Schott. F.A., T.N. Lee and R. Zantopp, 1988: Variability of structure and transpot of the Florida current in the period range of days (o) seasomal. J. Phys Oecemogr, $18,12(1)$ 1230. Ј 